\title{
Aerobic and Ligand-free Manganese-Catalyzed Homocoupling of Arenes or Aryl Halides via in-situ Formation of Aryllithiums
}

\author{
Yujia Liu, ${ }^{\dagger}$ Julien Bergèss, ${ }^{\dagger}$ Yassir Zaid, ${ }^{\dagger}{ }^{\S}$ Fouad Ouazzani Chahdi, ${ }^{\S}$ Arie Van Der Lee, ${ }^{*}$ Dominique \\ Harakat, ${ }^{\nabla}$ Eric Clot, ${ }^{\dagger}$ Florian Jaroschik, ${ }^{\dagger}$ and Marc Taillefer* ${ }^{\dagger}{ }^{\dagger}$ \\ †Institut Charles Gerhardt Montpellier, UMR 5253 CNRS, Université de Montpellier, ENSCM, 8 rue de l'Ecole Normale, \\ 34296 Montpellier, France \\ ${ }^{\nabla}$ Institut de Chimie Moléculaire de Reims, UMR 7312 CNRS, Université de Reims, BP 1039, 51687 Reims, France \\ ${ }^{\S}$ Laboratoire chimie organique appliquée LCOA, Faculté des Sciences et Techniques, 30000 Fès, Maroc \\ †Institut Européen des Membranes, ENSCM, Université de Montpellier, UMR 5635 CNRS, 34095 Montpellier, France.
}

KEYWORDS. C-C coupling - Manganese - Aryllithium - Oxygen - Biaryls - Mechanism.

\begin{abstract}
Ligand-free manganese-catalyzed homocoupling of arenes or aryl halides can be carried out under aerobic conditions via the in situ formation of the corresponding aryllithiums. A wide range of biaryls and derivatives has been obtained and a mechanism involving monomeric manganese-oxo complexes has been proposed on the basis of DFT calculations.
\end{abstract}

Manganese, a cheap, abundant and non-toxic transition metal, is an excellent alternative to precious metals for homogeneous catalysis and an ever increasing number of methods allowing the manganese catalyzed $\mathrm{C}-\mathrm{H}, \mathrm{C}-\mathrm{O}, \mathrm{C}-\mathrm{N}, \mathrm{C}-\mathrm{X}$ or $\mathrm{C}-$ $\mathrm{C}$ bond formation has been reported over the last five years. ${ }^{1}$ Among them, in a strive towards more sustainable processes, several reactions involving the combination of catalytic amounts of Mn salts and ambient air have been successfully developed, such as the hydroxyazidation of olefins, ${ }^{2}$ the oxytrifluoromethylation of styrene derivatives, ${ }^{3}$ the cyclization of unsaturated oximes ${ }^{4}$ or the coupling of Grignard reagents. ${ }^{5}$ Mn-dioxygen complexes are also under strong investigation due to their role in biological photosynthetic processes. ${ }^{6}$ In this context we wondered whether air-sensitive aryllithium reagents could be employed under $\mathrm{MnCl}_{2} / \mathrm{O}_{2}$ conditions in order to provide a highly versatile and green entry to biaryls. The latter are found in numerous natural products, biologically active compounds, agrochemicals, commercial dyes, organic conductors and semi-conductors. ${ }^{7}$ Biaryls are usually obtained via transition metal catalyzed coupling reactions employing organometallic compounds ${ }^{7}$ including in some cases organolithium derivates. ${ }^{8}$ In this field the most recent work dedicated to the synthesis of symmetrical biaryls has been reported with a catalytic system combining an aryl halide, tert-butyllithium and palladium associated with carbene type ligands. ${ }^{8 \mathrm{k}}$

We herein present our preliminary results on the ligand-free $\mathrm{MnCl}_{2} / \mathrm{O}_{2}$ catalyzed homocoupling of aryllithium derivatives in-situ generated from aryl halides or via activation of aromatic $\mathrm{C}-\mathrm{H}$ bonds. The mechanism of this system, less costly and more favourable for toxicity issues than the methods based on palladium, has been investigated by ESI-MS and DFT calculations.

For the preliminary trials iodobenzene $(\mathrm{X}=\mathrm{I})$ and a simple and readily available manganese salt $\left(\mathrm{MnCl}_{2}\right.$ : purity $\left.99,998 \%\right)$ were chosen as the model substrate and precatalyst, respectively (Figure 1). After addition of THF, the temperature of the mixture, first maintained at $-78{ }^{\circ} \mathrm{C}$ for the generation under argon of the phenyllithium with $t$-BuLi (step a), was then increased up to $25{ }^{\circ} \mathrm{C}$ and the reaction medium was stirred under argon for 1 hour (step b). Under these conditions, the expected biphenyl 1 was obtained but only with a $20 \%$ yield.

Figure 1. Mn-catalyzed synthesis of biphenyl 1 from chloro-, bromo- or iodobenzene, in the presence of $t$-BuLi. ${ }^{a}$

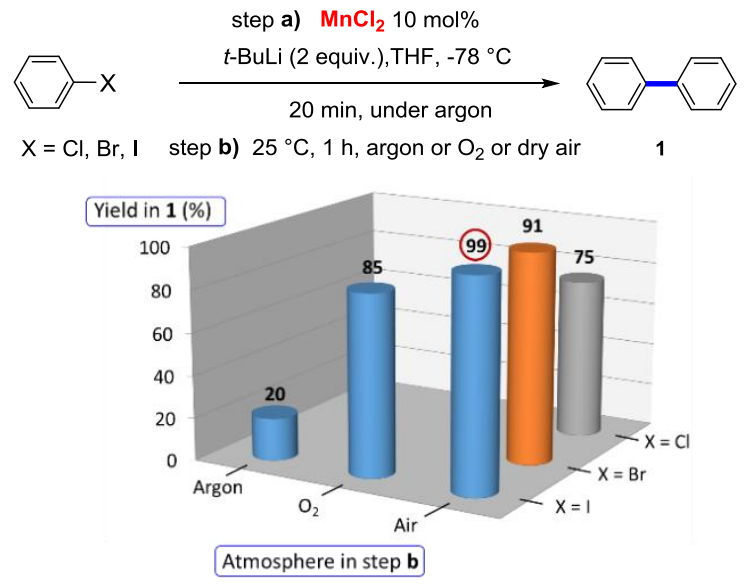

${ }^{a}$ Step a) $\mathrm{Ar}-\mathrm{X}(0.5 \mathrm{mmol}), \mathrm{MnCl}_{2}(0.05 \mathrm{mmol}, 99.998 \%$, Sigma Aldrich), $t$-BuLi (1.0 mmol), THF $(2 \mathrm{~mL}),-78{ }^{\circ} \mathrm{C}, 20 \mathrm{~min}$, under argon; step b) $25^{\circ} \mathrm{C}, 1 \mathrm{~h}$, argon, $\mathrm{O}_{2}$ or dry air. ${ }^{b}$ Yield determined by ${ }^{1} \mathrm{H}$ NMR using 1,3,5-trimethoxybenzene as internal standard.

The presence of one equivalent of a potential ligand $(1,10$ phenanthroline), or of a neutral Lewis base (TMEDA or trimethylamine) did not improve the system (see the Table S1 in SI). A very significant enhancement of the yield for $\mathbf{1}$ (85 $\%$ ) was obtained when argon was exchanged by dioxygen $\left(\mathrm{O}_{2}\right)$ once the mixture reached $25^{\circ} \mathrm{C}$ (step b). Finally, when step b was performed under atmospheric, dry air, we were pleased to observe the almost quantitative formation of biphenyl (99\%) and this was also the case starting from the less reactive bro- 
mobenzene ( $\mathrm{X}=\mathrm{Br}$ : 91\%). Remarkably, a good yield in biphenyl $1(75 \%)$ was achieved from the even more challenging chlorobenzene $(\mathrm{X}=\mathrm{Cl}$ ) (Figure 1). Solutions of $s$-BuLi or $n$ BuLi also provided biphenyl $\mathbf{1}$ in good yields but this was not the case with the other manganese salts we tested (see the Table S1 and Figure S1 in SI). Finally, complete absence of 1 was observed when blank experiments were carried out without manganese.

We next studied the substrate scope applying the optimized reaction conditions to various substrates with both electrondonating (EDG) and electron-withdrawing (EWG) groups on the aromatic ring (Table 1). With bromotolyl and bromoanisyl derivatives, the reaction was successfully performed to give the expected products 2-7 with good to excellent yields wherever the substituents (-Me and -OMe) were located (ortho-, meta-, para-position).

Table 1. Mn-catalyzed homocoupling of aryl- and benzylic halides in the presence of $t$-BuLi : synthesis of compounds 1-21 and triphenylene derivatives $22-23$.
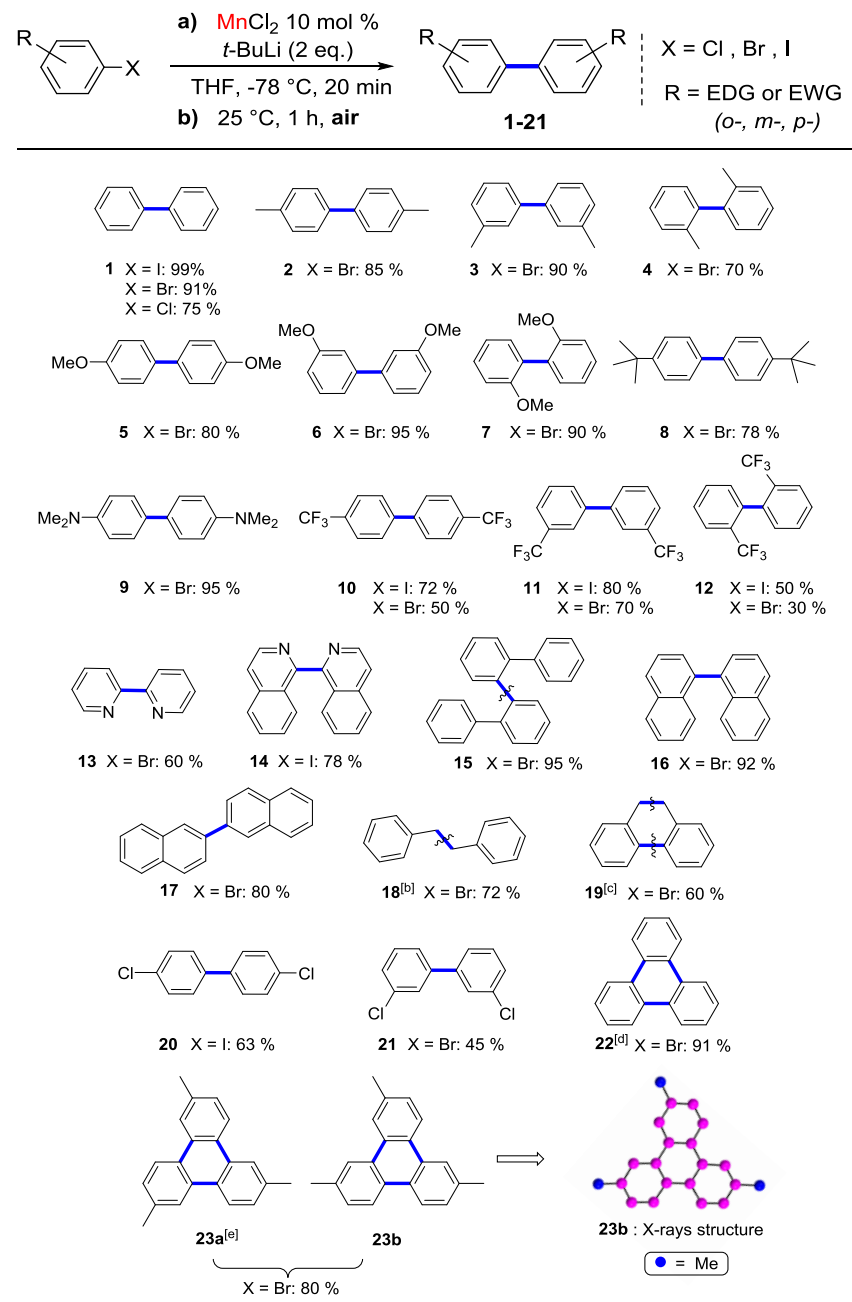

Isolated yields. ${ }^{a}$ Reaction conditions: a) $\mathrm{ArX}$ (1.0 mmol), $\mathrm{MnCl}_{2}$ (0.1 mmol, $99.998 \%$, Sigma Aldrich), $t$-BuLi (2.0 mmol), THF (4 $\mathrm{mL}),-78{ }^{\circ} \mathrm{C}, 20 \mathrm{~min}$, under argon; b) $25{ }^{\circ} \mathrm{C}, 1 \mathrm{~h}$, dry air. Starting material: ${ }^{b}$ benzyl bromide; ${ }^{c}$ 1-bromo-2-(bromomethyl)benzene; ${ }^{d}$ $o$-chlorobromobenzene; ${ }^{e} 3$-bromo-4-chlorotoluene.

A high yield (78\%) was obtained with tert-butyl in the para position to generate 4,4'-di-tert-butyl-1,1'-biphenyl $\mathbf{8}$ which is a direct precursor of Freeman's reagent ${ }^{9}$ and we succeeded in scaling up to $10 \mathrm{mmol}$ without decreasing the output. $N 4, N 4, N 4$ ', $N 4$ '-tetramethyl-[1,1'-biphenyl]-4,4'-diamine 9 was also obtained almost quantitatively. We then attempted substrates with electron-withdrawing groups. Good yields were achieved from $p$ - and $m$-trifluoromethyl bromobenzene (biphenyls 10, 11). When the trifluoromethyl group was in the ortho-position, only $30 \%$ of the corresponding biaryl 12 was obtained. The reduction product and a small amount of corresponding phenol derivate were then also observed. Starting from the iodide derivative, for which the lithium-halide exchange rate is higher than the bromide derivative, ${ }^{10}$ led to an increase in the yields of $\mathbf{1 2}$ to $50 \%$. Two heteroaryl halides were successfully transformed to 2,2'-bipyridine and 1,1'biisoquinoline $(\mathbf{1 3}, \mathbf{1 4})$, which are well known as ligands for transition metal complexes. ${ }^{11} \mathrm{We}$ then carried out the homocoupling reactions with larger substrates such as 2-bromo1,1'-biphenyl, 1-bromonaphtalene and 2-bromonaphtalene and excellent yields were acquired $(\mathbf{1 5}, \mathbf{1 6}, \mathbf{1 7})$. These products are common material precursors and are used to synthesize large size polycyclic aromatic compounds. ${ }^{12}$ In addition, the reaction works well for benzyl bromide leading to 1,2-diphenyl ethane 18. This offers an alternative approach to the known methods $^{13}$ for the synthesis of 9,10-dihydrophenanthrene 19, which we obtained via the double dimerization of 1-bromo-2(bromomethyl)benzene. To extend again the application field of the method, we also performed some tests on polyhalobenzenes. The latter are promising substrates, as the resulting biaryls can be readily further functionalised. Starting from the $p$-chloroiodobenzene and $m$-chlorobromobenzene, fair to good yields of expected 4,4'- and 3,3'-dichlorobiphenyl (20,63\%; 21, $45 \%$ ) were obtained. With the $o$-chlorobromo analogue we did not observe any homocoupling product but instead the polycyclic aromatic triphenylene 22 was obtained in $91 \%$. As triphenylene derivatives are attractive compounds in supramolecular and material fields, ${ }^{14}$ we then tested a methylsubstituted $o$-chlorobromobenzene and the corresponding two triphenylene isomers (23a and 23b) were obtained with a $80 \%$ yield and ratio $1 / 3$. 23b was recrystallized and its $X$-ray structure showed that the molecules are essentially planar and stacked in layers parallel to the plane (see Figures S2, S3 in SI). Within these planes they are arranged in chains connected by very weak van der Waals interactions between methyl moieties (Figure S4).

Table 2. Mn-catalyzed homocoupling of acetylene or arene via C-H activation. ${ }^{a}$

$$
\begin{array}{ll}
\text { a) } \mathrm{MnCl}_{2} 10 \mathrm{~mol} \% \\
\mathrm{R}-\mathrm{H}-\frac{\mathrm{t}-\mathrm{BuLi}(1.1 \text { equiv) }}{\mathrm{THF},-78^{\circ} \mathrm{C}, 20 \mathrm{~min}} \\
\\
\text { b) } 25^{\circ} \mathrm{C}, 1 \mathrm{~h} \text {, air }
\end{array}
$$
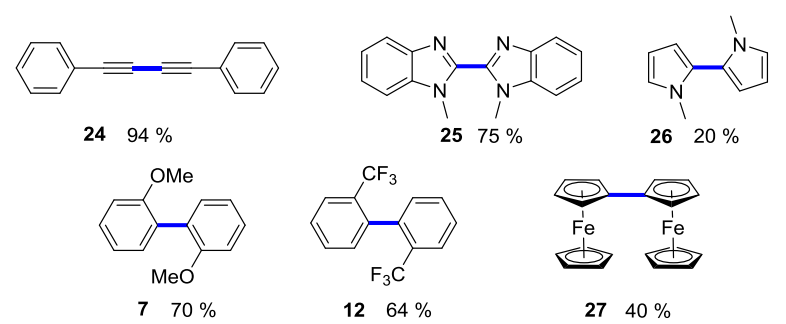

Isolated yields. ${ }^{a}$ a) phenylacetylene or arene (1.0 mmol), $\mathrm{MnCl}_{2}$ (0.1 mmol, $99.998 \%$, Sigma Aldrich), $t$-BuLi (1.1 mmol), THF (4 $\mathrm{mL}),-78^{\circ} \mathrm{C}, 20 \mathrm{~min}$, under argon; b) $25^{\circ} \mathrm{C}, 1 \mathrm{~h}$, dry air. 
In further substrate scope studies, we succeeded in applying the catalytic system to acetylene or arene derivatives possessing an activated $\mathrm{C}-\mathrm{H}$ bond (Table 2 ). We have thus performed the homocoupling reactions of phenylacetylene and of 1methyl-1H-benzo[d]imidazole to give 1,4-diphenylbuta-1,3diyne 24 and 1,1'-dimethyl-1H,1'H-2,2'-bibenzo[d]imidazole 25, respectively, in very good yield. Starting from $\mathrm{N}$ methylpyrrole, only poor yield of corresponding product $\mathbf{2 6}$ was obtained. However 2,2'-dimethoxy-1,1'-biphenyl 7 was synthesized directly from anisole via directed ortho metalation. ${ }^{15}$ It is worth noting that from trifluoromethylbenzene, for which the strong electron-withdrawing inductive effect of $\mathrm{CF}_{3}$ promotes the formation of ortho-lithiated intermediate, 2,2'ditrifluoromethyl-1,1'-biphenyl $\mathbf{1 2}$ was obtained in higher yields than starting from arylhalides. ${ }^{16}$ Interestingly, biferrocene 27 , investigated in the field of molecular electronics ${ }^{17}$ and usually gained through the use of haloferrocenes via an Ullmann coupling reaction, ${ }^{18}$ was synthesized using this catalytic system via $\mathrm{C}-\mathrm{H}$ activation on the cyclopentadienyl ring.

To interpret the role of dioxygen, a key factor for the efficiency of this system in the homocoupling reactions, we monitored the reaction by electrospray ionization mass spectrometry (ESI-MS). Various aryl halides were tested and in order to detect more easily the potential formation of metal intermediates, a stoichiometric amount of $\mathrm{MnCl}_{2}(50 \mathrm{~mol} \%)$ was used. After exposure of the reaction mixture to air, the most interpretable spectrum was obtained when 1-chloro-4-iodobenzene was used as substrate due to the existence of isotopes of chlorine atom, which facilitates the identification of the intermediate compounds. In this case a peak at $\mathrm{m} / \mathrm{z}=624.8309$ corresponding to an empirical formula $\mathrm{C}_{24} \mathrm{H}_{16} \mathrm{Cl}_{4} \mathrm{Mn}_{2} \mathrm{O}_{2} \mathrm{~K}$ was observed (Figure 2). It is worth noting that the experimental spectrum matches well with the theoretical one.

Figure 2. Theoretical (above) and observed (below) spectra of ESI-MS analysis of possible manganese dimers $\mathbf{A}, \mathbf{A}^{\prime}$ or A".
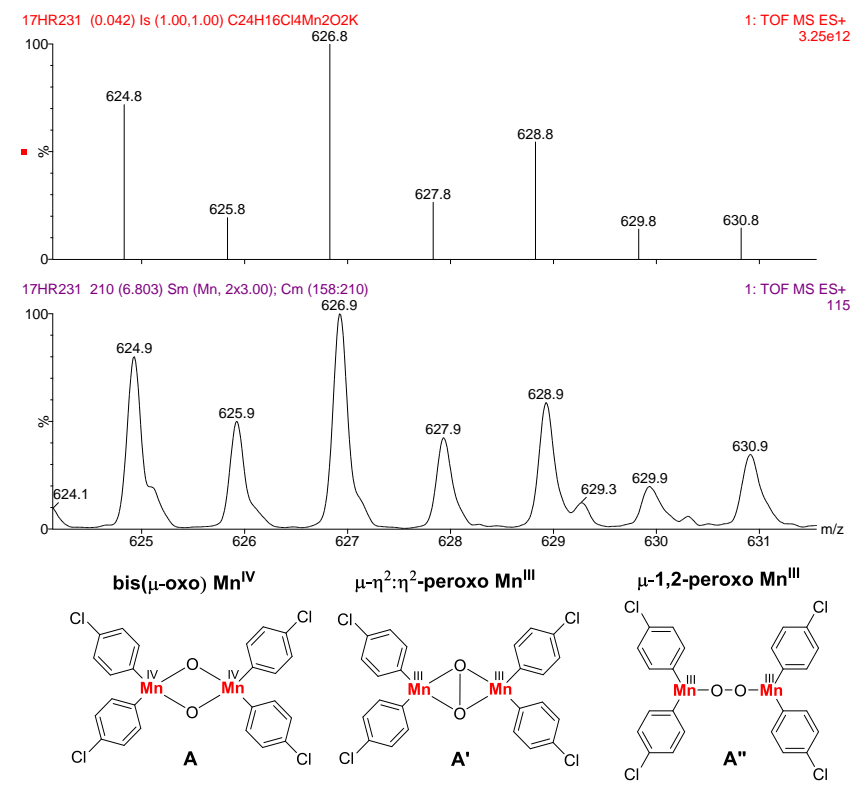

The formula of this compound, that we could not detect under Mn-catalytic conditions, corresponds to either a bis( $\mu$-oxo) manganese (IV) dimer $\mathbf{A}$, or a $\mu-\eta^{2}: \eta^{2}$-peroxo manganese (III) dimer A', or a $\mu$-1,2-peroxo manganese (III) dimer $\mathbf{A}^{\prime \prime}$ (Figure 2 ). If the existence of a structure as dimer $\mathbf{A}^{\prime}$ has not been proven yet, the related dimers $\mathbf{A}$ and $\mathbf{A}$ " have been already described with polydentate thiolate and nitrogen ligands. ${ }^{6}$ DFT(PBE-D3) calculations were then carried out on the dimer to elucidate the nature of the bonding pattern. ${ }^{19}$ Despite many attempts, no linear structure such as A" could be located on the potential energy surface. A symmetric structure, Dimer-1, similar to structure $\mathbf{A}$, could be optimized as a singlet. The four $\mathrm{Mn}-\mathrm{O}$ bond distances are identical $(1.745 \AA)$ and there is no significant bonding interaction between the two oxygen atoms $(\mathrm{O} \ldots \mathrm{O}=2.560 \AA)($ see Figure S5 in the SI). A triplet geometry, Dimer-2, was located at $\Delta \mathrm{G}=-6.4 \mathrm{kcal} \mathrm{mol}^{-1}$ with respect to Dimer-1. In the distorted triplet, the O...O distance is still too long $(2.670 \AA)$ to invoke any bonding interaction. The spin density (Figure S6 in the SI) is evenly shared between the two Mn atoms (1.077), and Dimer-2 can be described as an oxo-bridged $\mathrm{Mn}^{\mathrm{IV}}-\mathrm{Mn}^{\mathrm{IV}}$ dimer. Another triplet structure, Dimer-3, could be optimized at $\Delta \mathrm{G}=-23.3 \mathrm{kcal}$ $\mathrm{mol}^{-1}$ with respect to Dimer-1. This structure presents two different Mn centers, with one having two long Mn-O bond distances $(2.028 \AA)$ and the other having two short Mn-O bond distances (1.662 $\AA$ ). The O...O distance is still too long (2.592 $\AA$ ) to invoke any bonding interaction. The spin density (Figure S6) is not evenly shared between the two Mn atoms (4.076 vs. -1.621 ) and Dimer-3 is best described as a $\mathrm{Mn}^{\mathrm{II}} / \mathrm{Mn}^{\mathrm{VI}}$ dimer. The DFT calculations are thus indicating that the dimer observed in the ESI-MS experiment is most likely a formally $\mathrm{Mn}^{\mathrm{II}} / \mathrm{Mn}^{\mathrm{VI}}$ structure without any direct O...O nor Mn...Mn interaction. However, attempts to locate transition state structures associated to $\mathrm{C}-\mathrm{C}$ bond formation on any of the $\mathrm{Mn}$ centers in Dimer-3 failed. Therefore calculations could not support that such dimeric structure is a competent catalyst for the biaryl formation.

Scheme 1. Proposed mechanism for biaryl formation as deduced from the DFT calculations.

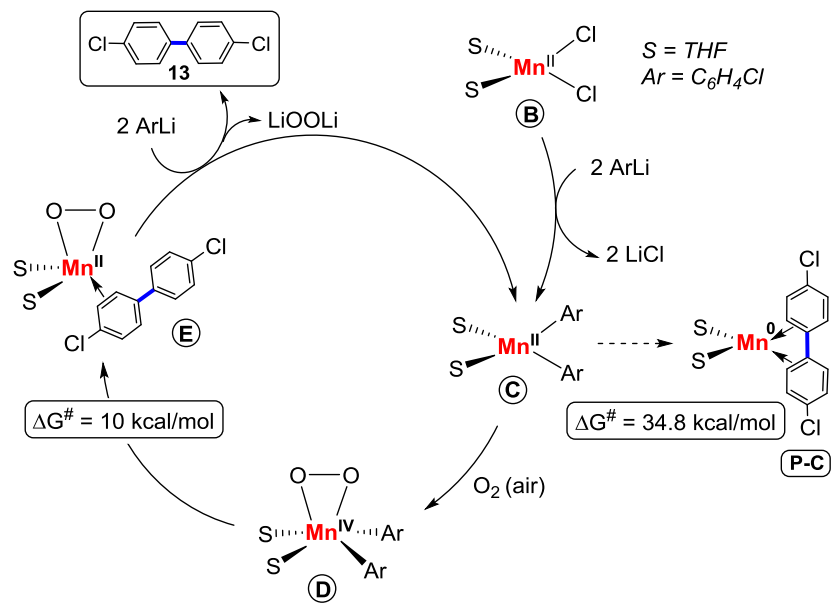

DFT calculations were then carried out to probe the mechanistic hypothesis depicted in Scheme $\mathbf{1}$ based on the involvement of Mn monomeric species. In situ generated aryllithium would first react with $\mathrm{MnCl}_{2}$ salt probably coordinated with the solvent $(\mathrm{S}=\mathrm{THF})$ to generate a catalytic amount of diarylmanganese(II) $\mathbf{C}$ intermediate. ${ }^{20}$ From $\mathbf{C}$, a transition state structure, TS-C, associated to $\mathrm{C}-\mathrm{C}$ bond formation could be located with an activation barrier of $\Delta \mathrm{G}^{\#}=34.8 \mathrm{kcal} \mathrm{mol}^{-1}$. This transformation is only slightly exergonic $(\Delta \mathrm{G}=-1 \mathrm{kcal}$ $\mathrm{mol}^{-1}$ ) and the product of the reaction, P-C, is a complex between the biaryl 13 and a $\operatorname{Mn}(0)$ fragment $\left(\mathrm{Mn}(\mathrm{THF})_{2}\right)$. The 
value of the activation barrier is not compatible with a reaction time of 1 hour at room temperature. This is in perfect agreement with the lack of catalytic activity under inert atmosphere. However, DFT showed a more favourable route for which the oxidation of $\mathbf{C}$ in the presence of dioxygen leads to the exergonic $\left(\Delta \mathrm{G}=-42.6 \mathrm{kcal} \mathrm{mol}^{-1}\right)$ formation of a $\eta^{2}$-oxo manganese (IV) intermediate $\mathbf{D} .^{5}$ The activation barrier for $\mathrm{C}-\mathrm{C}$ bond formation through TS-D on this oxidized manganese complex is significantly reduced with $\Delta \mathrm{G}^{\#}=10.0 \mathrm{kcal} \mathrm{mol}^{-1}$. The transformation is exergonic $\left(\Delta \mathrm{G}=-12.6 \mathrm{kcal} \mathrm{mol}^{-1}\right)$ and the product $\mathbf{E}$ is a $\pi$-complex of the biaryl $\mathbf{1 3}$ on the $\mathrm{Mn}$ (II) oxo complex $\mathrm{Mn}\left(\mathrm{O}_{2}\right)(\mathrm{THF})_{2}$. In the presence of two equivalents of aryl lithium, the biaryl would be expelled and the catalytic species $\mathrm{C}$ regenerated, releasing the lithium peroxide $\left(\mathrm{Li}_{2} \mathrm{O}_{2}\right)$. The dimer observed in the ESI-MS experiment under non-catalytic conditions could be the result of an $\mathrm{O}-\mathrm{O}$ oxidative addition in D stabilized by interaction with $\mathbf{C}$ resulting in the $\mathrm{Mn}(\mathrm{II}) / \mathrm{Mn}(\mathrm{IV})$ dimer.

In conclusion, we have disclosed original conditions for the synthesis of a wide range of symmetrical biaryls and derivatives such as biferrocene, 9,10-dihydrophenanthrene or even triphenylene derivatives. These molecules are obtained by using a ligand-free manganese catalytic system allowing the homocoupling of arenes (C-H activation) or aryl halides (C-X activation), via the intermediate formation of aryllithiums derivatives. The experiments together with the DFT calculations highlight the crucial role of dioxygen in the catalytic process. A mechanistic hypothesis based on the involvement of $\mathrm{Mn}$ monomeric species and on a $\mathrm{Mn}(\mathrm{II}) / \mathrm{Mn}(\mathrm{IV})$ sequence has been proposed. Work is in progress in our laboratory to further extend the application field of the system and to gain a deeper understanding of the mechanism.

\section{EXPERIMENTAL SECTION}

General Information. All reactions were performed in flame-dried Schlenk flasks under an atmosphere of argon. THF was distilled from sodium/benzophenone, stored on $4 \AA$ activated molecular sieves under an argon atmosphere. $\mathrm{MnCl}_{2}$ $(99.998 \%)$ was purchased from Sigma-Aldrich ${ }^{\circledR}$, stored in a Schlenk flask under an atmosphere of argon. All other reagents were purchased from Sigma-Aldrich ${ }^{\circledR}$, Alfa Aesar ${ }^{\circledR}$ or Acros $^{\circledR}$ and used as received, without further purification. All reagents were weighed in the air. ${ }^{1} \mathrm{H},{ }^{13} \mathrm{C}$ and ${ }^{19} \mathrm{~F}$ NMR spectra were recorded on a Bruker $\mathrm{AC} 400 \mathrm{MHz}$ spectrometer in $\mathrm{CDCl}_{3}$. For ${ }^{1} \mathrm{H}$ NMR (400 MHz), $\mathrm{CHCl}_{3}$ and TMS served as internal standards $(\delta=7.27$ and $0 \mathrm{ppm})$ and data are reported as follows: chemical shift (in ppm), multiplicity ( $\mathrm{s}=$ singlet, br $\mathrm{s}=$ broad singlet, $\mathrm{d}=$ doublet, $\mathrm{t}=$ triplet, $\mathrm{m}=$ multiplet , , coupling constant (in $\mathrm{Hz}$ ), and integration. For ${ }^{13} \mathrm{C}$ NMR (101 $\mathrm{MHz}), \mathrm{CHCl}_{3}$ was used as internal standard $(\delta=77.2 \mathrm{ppm})$ and spectra were obtained with complete proton decoupling. High-resolution mass spectra (HRMS) were recorded on an Agilent 6210 ESI TOF (time of flight) mass spectrometer or on a JEOL JMS-DX300 mass spectrometer (3 keV, xenon) in an $m$-nitrobenzylalcohol matrix. For the ESI-MS mechanistic studies high resolution ESI-MS spectra were recorded on a hybrid tandem quadrupole/time-of-flight (Q-TOF) instrument, equipped with a pneumatically assisted electrospray (Z-spray) ion source (Micromass, Manchester, UK) operated in positive mode. Flash column chromatography was performed on Silicycle silica gel (230-400 mesh) or Merck Geduran Si 60 silica gel (40-63 $\mu \mathrm{m})$ and analytical thin-layer chromatography
(TLC) was carried out using $250 \mu \mathrm{m}$ silica gel plates. Visualization of the developed chromatograms was performed by UV irradiation $(254 \mathrm{~nm})$.

General Note on Safety. Organolithium compounds are highly reactive and generally pyrophoric, the use of them thus requires great caution and proper lab bench conditions. ${ }^{21}$ Tertbutyllithium can easily catch fire and form peroxides on exposure to air and react violently with water, so the first step of the reactions should be carried out under strict air-free and water-free conditions. ${ }^{21 \mathrm{~b}}$ In our case, before exposure the reaction mixture to dry air, tert-butyllithium has already reacted with aryl halides and turned to the corresponding aryllithium compounds which are much less pyrophoric. In addition, at the end of reaction we did not observe the formation of peroxides - a test was performed before the work-up of the reaction mixture.

General procedure 1 for the synthesis of symmetrical biaryls from arylhalides. After standard cycles of evacuation and back-filling with dry and pure argon, an oven-dried Schlenk flask equipped with a magnetic stirring bar was charged with $\mathrm{MnCl}_{2}$ ( $0.1 \mathrm{mmol}, 0.1$ equiv.). The flask was evacuated and back-filled with argon, then dry THF (4 mL) and aryl halide (1.0 mmol, 1.0 equiv.). Then the flask was stirred, cooled to $-78{ }^{\circ} \mathrm{C}$ and $t$-BuLi ( $2.0 \mathrm{mmol}, 2.0$ equiv. 1.1 $\mathrm{ml}$ of a $1.9 \mathrm{M}$ solution in pentane) or $s$-BuLi (2.0 mmol, 2.0 equiv., and $1.5 \mathrm{ml}$ of a $1.3 \mathrm{M}$ solution in cyclohexane/hexane - 92/8) was added under a stream of argon by syringe. The reaction mixture was stirred for about 20 minutes at $-78{ }^{\circ} \mathrm{C}$ and then heated to room temperature. The air was introduced when the screwed cap of flask was replaced by a guard tube filled with silica gel. The reaction mixture was stirred at room temperature for 1 hour. Then, 1, 3,5-trimethoxybenzene (16.8 $\mathrm{mg}, 0.1 \mathrm{mmol})$ was added as internal standard. The resulting mixture was diluted with $\mathrm{Et}_{2} \mathrm{O}(10 \mathrm{~mL})$ and washed with $\mathrm{NH}_{4} \mathrm{Cl}$ saturated solution $(3 \times 15 \mathrm{~mL})$. The aqueous layer was washed with $\mathrm{Et}_{2} \mathrm{O}(3 \mathrm{x} 10 \mathrm{~mL})$. The organic layer was dried over anhydrous $\mathrm{MgSO}_{4}$ and diethyl ether was evaporated under reduced pressure (rotary evaporator). The residue was purified by column chromatography to give the desired symmetrical biaryl.

General procedure 2 for the synthesis of symmetrical biaryls via C-H activation. After standard cycles of evacuation and back-filling with dry and pure argon, an oven-dried Schlenk flask equipped with a magnetic stirring bar was charged with $\mathrm{MnCl}_{2}$ (0.1 mmol, 0.1 equiv.). The flask was evacuated and back-filled with argon, then dry THF (4 mL) and aryl halide (1.0 mmol, 1.0 equiv.). Then the flask was stirred, cooled to $-78^{\circ} \mathrm{C}$ and $t$-BuLi ( $1.0 \mathrm{mmol}, 1.0$ equiv. 0.55 $\mathrm{ml}$ of a $1.9 \mathrm{M}$ solution in pentane) was added under a stream of argon by syringe. The reaction mixture was stirred for about 20 minutes at $-78{ }^{\circ} \mathrm{C}$ and then heated to room temperature. The air was introduced when the screwed cap of flask was replaced by a guard tube filled with silica gel. The reaction mixture was stirred at room temperature for 1 hour. Then, 1 , 3,5-trimethoxybenzene $(16.8 \mathrm{mg}, 0.1 \mathrm{mmol})$ was added as internal standard. The resulting mixture was diluted with $\mathrm{Et}_{2} \mathrm{O}$ $(10 \mathrm{~mL})$ and washed with $\mathrm{NH}_{4} \mathrm{Cl}$ saturated solution $(3 \times 15$ $\mathrm{mL})$. The aqueous layer was washed with $\mathrm{Et}_{2} \mathrm{O}(3 \times 10 \mathrm{~mL})$. The organic layer was dried over anhydrous $\mathrm{MgSO}_{4}$ and diethyl ether was evaporated under reduced pressure (rotary evaporator). The residue was purified by column chromatography to give the desired symmetrical biaryl. 
1,1'-biphenyl (1). ${ }^{5 a}$ Yield: $152.6 \mathrm{mg}, 99 \%(\mathrm{X}=\mathrm{I}) ; 140.3 \mathrm{mg}$, $91 \%(\mathrm{X}=\mathrm{Br}) ; 115.7 \mathrm{mg}, 75 \%(\mathrm{X}=\mathrm{Cl}) .{ }^{1} \mathrm{H} \mathrm{NMR}(400 \mathrm{MHz}$, $\left.\mathrm{CDCl}_{3}\right) \delta: 7.59(\mathrm{~d}, J=7.1 \mathrm{~Hz}, 4 \mathrm{H}), 7.44(\mathrm{t}, J=7.6 \mathrm{~Hz}, 4 \mathrm{H})$, $7.34(\mathrm{t}, J=7.4 \mathrm{~Hz}, 2 \mathrm{H}) .{ }^{13} \mathrm{C}\left\{{ }^{1} \mathrm{H}\right\}$ NMR $\left(101 \mathrm{MHz}, \mathrm{CDCl}_{3}\right) \delta$ : 141.4, 128.9, 127.43, 127.35. GC-MS: $\mathrm{rt}=7.17 \mathrm{~min}, \mathrm{~m} / \mathrm{z}=$ 154. Column chromatography: $\mathrm{SiO}_{2}, n$-Pentane $100 \%$.

4,4'-dimethyl-1,1'-biphenyl (2). ${ }^{22}$ Yield: $154.9 \mathrm{mg}, 85 \%(\mathrm{X}=$ Br). ${ }^{1} \mathrm{H}$ NMR (400 MHz, $\left.\mathrm{CDCl}_{3}\right) \delta: 7.56(\mathrm{~d}, J=8.1,4 \mathrm{H}), 7.31$ $(\mathrm{d}, J=8.1,4 \mathrm{H}), 2.46(\mathrm{~s}, 6 \mathrm{H}) .{ }^{13} \mathrm{C}\left\{{ }^{1} \mathrm{H}\right\} \mathrm{NMR}\left(101 \mathrm{MHz}, \mathrm{CDCl}_{3}\right)$ $\delta: 138.4,136.9,129.6,127.0,21.3 . \mathrm{GC}-\mathrm{MS}: \mathrm{rt}=8.36 \mathrm{~min}, \mathrm{~m} / \mathrm{z}$ $=182$. Column chromatography: $\mathrm{SiO}_{2}, n$-Pentane $100 \%$.

3,3'-dimethyl-1,1'-biphenyl (3). ${ }^{22}$ Yield: $164.0 \mathrm{mg}, 90 \%(\mathrm{X}=$ $\mathrm{Br}) .{ }^{1} \mathrm{H}$ NMR (400 MHz, $\mathrm{CDCl}_{3}$ ) $\delta: ~ 7.46-7.44(\mathrm{~m}, 4 \mathrm{H}), 7.37$ $(\mathrm{t}, J=7.5,2 \mathrm{H}), 7.21(\mathrm{t}, J=7.5,2 \mathrm{H}), 2.47(\mathrm{~s}, 6 \mathrm{H}) .{ }^{13} \mathrm{C}\left\{{ }^{1} \mathrm{H}\right\}$ NMR (101 MHz, $\left.\mathrm{CDCl}_{3}\right) \delta: 141.5,138.4,128.8,128.14$, 128.08, 124.5, 21.7. GC-MS: $\mathrm{rt}=8.24 \mathrm{~min}, \mathrm{~m} / \mathrm{z}=182$. Column chromatography: $\mathrm{SiO}_{2}, n$-Pentane $100 \%$.

2,2'-dimethyl-1,1'-biphenyl (4). ${ }^{22}$ Yield: $127.6 \mathrm{mg}, 70 \%(\mathrm{X}=$ $\mathrm{Br}) .{ }^{1} \mathrm{H} \mathrm{NMR}\left(400 \mathrm{MHz}, \mathrm{CDCl}_{3}\right) \delta: 7.28-7.19(\mathrm{~m}, 6 \mathrm{H}), 7.10$ $(\mathrm{d}, J=6.8 \mathrm{~Hz}, 2 \mathrm{H}), 2.06(\mathrm{~s}, 6 \mathrm{H}) .{ }^{13} \mathrm{C}\left\{{ }^{1} \mathrm{H}\right\} \mathrm{NMR}(101 \mathrm{MHz}$, $\left.\mathrm{CDCl}_{3}\right) \delta: 141.8,136.0,130.0,129.5,127.3,125.7,20.0 . \mathrm{GC}-$ MS: $\mathrm{rt}=7.36 \mathrm{~min}, \mathrm{~m} / \mathrm{z}=182$. Column chromatography: $\mathrm{SiO}_{2}$, $n$-Pentane $100 \%$.

4,4'-dimethoxy-1,1'-biphenyl (5) ${ }^{23}$ Yield: $171.4 \mathrm{mg}, 80 \%(\mathrm{X}$ $=\mathrm{Br}) .{ }^{1} \mathrm{H} \mathrm{NMR}\left(400 \mathrm{MHz}, \mathrm{CDCl}_{3}\right) \delta: 7.49(\mathrm{~d}, J=8.8 \mathrm{~Hz}$, $4 \mathrm{H}), 6.98(\mathrm{~d}, J=8.8 \mathrm{~Hz}, 4 \mathrm{H}), 3.86(\mathrm{~s}, 6 \mathrm{H}) .{ }^{13} \mathrm{C}\left\{{ }^{1} \mathrm{H}\right\} \mathrm{NMR}$ $\left(101 \mathrm{MHz} \mathrm{CDCl}_{3}\right) \delta: 158.9,133.7,127.9,114.4,55.5$. GCMS: $\mathrm{rt}=9.77 \mathrm{~min}, \mathrm{~m} / \mathrm{z}=214$. Column chromatography: $\mathrm{SiO}_{2}$, $n$-Pentane/DCM 50/50.

3,3'-dimethoxy-1,1'-biphenyl $(6)^{24}$ Yield: $203.5 \mathrm{mg}, 95 \%$ (X $=\mathrm{Br}) .{ }^{1} \mathrm{H} \mathrm{NMR}\left(400 \mathrm{MHz}, \mathrm{CDCl}_{3}\right) \delta: 7.40(\mathrm{t}, J=7.9 \mathrm{~Hz}$, $2 \mathrm{H}), 7.23(\mathrm{~d}, J=7.9 \mathrm{~Hz}, 2 \mathrm{H}), 7.18(\mathrm{t}, J=2.4 \mathrm{~Hz}, 2 \mathrm{H}), 6.95$ $(\mathrm{dd}, J=8.2,2.4 \mathrm{~Hz}, 2 \mathrm{H}), 3.90(\mathrm{~s}, 6 \mathrm{H}) .{ }^{13} \mathrm{C}\left\{{ }^{1} \mathrm{H}\right\}$ NMR $(101$ $\left.\mathrm{MHz}, \mathrm{CDCl}_{3}\right) \delta: 160.1,142.8,129.9,119.8,113.1,112.9$, 55.4. GC-MS: $\mathrm{rt}=9.61 \mathrm{~min}, \mathrm{~m} / \mathrm{z}=214$. HRMS $\left(\mathrm{ESI}^{+}\right) \mathrm{m} / \mathrm{z}$ : $[\mathrm{M}+\mathrm{H}]^{+}$Calcd. for $\mathrm{C}_{14} \mathrm{H}_{15} \mathrm{O}_{2}$ 215.1072; Found : 215.1074 . Column chromatography: $\mathrm{SiO}_{2}, n$-Pentane/DCM 50/50.

2,2'-dimethoxy-1,1'-biphenyl (7) ${ }^{5 a}$ Yield: $192.8 \mathrm{mg}, 90 \%(\mathrm{X}$ $=\mathrm{Br}) ; 150.0 \mathrm{mg}, 70 \%(\mathrm{X}=\mathrm{H}) .{ }^{1} \mathrm{H} \mathrm{NMR}\left(400 \mathrm{MHz}, \mathrm{CDCl}_{3}\right)$ $\delta: 7.38-7.32(\mathrm{~m}, 2 \mathrm{H}), 7.27(\mathrm{dd}, J=7.5,1,7 \mathrm{~Hz}, 2 \mathrm{H}), 7.06-$ $6.97(\mathrm{~m}, 4 \mathrm{H}), 3.79(\mathrm{~s}, 6 \mathrm{H}) .{ }^{13} \mathrm{C}\left\{{ }^{1} \mathrm{H}\right\}$ NMR $\left(101 \mathrm{MHz}, \mathrm{CDCl}_{3}\right)$ $\delta: 157.2,131.6,128.8,128.0,120.5,111.3,55.9$. GC-MS: rt = $8.67 \mathrm{~min}, \mathrm{~m} / \mathrm{z}=214$. HRMS $\left(\mathrm{ESI}^{+}\right) \mathrm{m} / \mathrm{z}:[\mathrm{M}+\mathrm{H}]^{+}$Calcd. for $\mathrm{C}_{14} \mathrm{H}_{15} \mathrm{O}_{2}$ 215.1072; Found : 215.1073. Column chromatography: $\mathrm{SiO}_{2}, n$-Pentane/DCM 50/50.

4,4'-di-tert-butyl-1,1'-biphenyl $(8)^{24}$ Yield: $207.8 \mathrm{mg}, 78 \%$ $(\mathrm{X}=\mathrm{Br}) . \quad{ }^{1} \mathrm{H} \mathrm{NMR}\left(400 \mathrm{MHz}, \mathrm{CDCl}_{3}\right) \delta: 7.56(\mathrm{~d}, J=8.4 \mathrm{~Hz}$, $4 \mathrm{H}), 7.48(\mathrm{~d}, J=8.4 \mathrm{~Hz}, 4 \mathrm{H}), 1.39(\mathrm{~s}, 18 \mathrm{H}) .{ }^{13} \mathrm{C}\left\{{ }^{1} \mathrm{H}\right\}$ NMR $\left(101 \mathrm{MHz}, \mathrm{CDCl}_{3}\right) \delta: 150.1,138.4,126.9,125.8,34.7,31.6$. GC-MS: $\mathrm{rt}=10.37 \mathrm{~min}, \mathrm{~m} / \mathrm{z}=266$. Column chromatography: $\mathrm{SiO}_{2}, n$-Pentane $100 \%$.

$N 4, N 4, N 4$ ',N4'-tetramethyl-[1,1'-biphenyl]-4,4'-diamine $(\mathbf{9})^{24}$ Yield: $228.3 \mathrm{mg}, 95 \%(\mathrm{X}=\mathrm{Br}) .{ }^{1} \mathrm{H}$ NMR (400 $\mathrm{MHz}, \mathrm{CDCl}_{3}$ ) $\delta: 7.49(\mathrm{~d}, J=8.5 \mathrm{~Hz}, 4 \mathrm{H}), 6.83(\mathrm{~d}, J=8.5 \mathrm{~Hz}, 4 \mathrm{H}), 3.00$ (s, $12 \mathrm{H}) .{ }^{13} \mathrm{C}\left\{{ }^{1} \mathrm{H}\right\}$ NMR (101 $\left.\mathrm{MHz}, \mathrm{CDCl}_{3}\right) \delta: 149.4,130.0$, 127.1, 113.3, 41.0. GC-MS: $\mathrm{rt}=11.41 \mathrm{~min}, \mathrm{~m} / \mathrm{z}=240$. HRMS $\left(\mathrm{ESI}^{+}\right) \mathrm{m} / \mathrm{z}:[\mathrm{M}+\mathrm{H}]^{+}$Calcd. for $\mathrm{C}_{16} \mathrm{H}_{21} \mathrm{~N}_{2}$ 241.1705; Found :
241.1703. Column chromatography: $\mathrm{SiO}_{2}, n$-Pentane/EtOAc $70 / 30$.

4,4'-bis(trifluoromethyl)-1,1'-biphenyl $\quad(\mathbf{1 0})^{22} \quad$ Yield: 209.0 $\mathrm{mg}, 72 \%(\mathrm{X}=\mathrm{I}) ; 145.1 \mathrm{mg}, 50 \%(\mathrm{X}=\mathrm{Br}) .{ }^{1} \mathrm{H}$ NMR $(400$ $\left.\mathrm{MHz}, \mathrm{CDCl}_{3}\right) \delta: 7.77-7.71(\mathrm{~m}, 8 \mathrm{H}) .{ }^{13} \mathrm{C}\left\{{ }^{1} \mathrm{H}\right\}$ NMR $(101 \mathrm{MHz}$, $\left.\mathrm{CDCl}_{3}\right) \delta: 143.4,130.5(\mathrm{q}, J=32.7 \mathrm{~Hz}), 127.8,126.1(\mathrm{q}, J=$ $3.7 \mathrm{~Hz}), 124.1(\mathrm{q}, J=272.0 \mathrm{~Hz}) .{ }^{19} \mathrm{~F} \mathrm{NMR}\left(377 \mathrm{MHz}, \mathrm{CDCl}_{3}\right)$ $\delta$ : -62.56. GC-MS: $\mathrm{rt}=7.16 \mathrm{~min}, \mathrm{~m} / \mathrm{z}=290$. Column chromatography: $\mathrm{SiO}_{2}, n$-Pentane $100 \%$.

3,3'-bis(trifluoromethyl)-1,1'-biphenyl (11) ${ }^{22}$ Yield: 232.2 $\mathrm{mg}, 80 \%$ (X = I); $203.1 \mathrm{mg}, 70 \%(\mathrm{X}=\mathrm{Br}) .{ }^{1} \mathrm{H}$ NMR $(400$ $\left.\mathrm{MHz}, \mathrm{CDCl}_{3}\right) \delta: 7.85(\mathrm{~d}, \mathrm{~J}=0.5 \mathrm{~Hz}, 2 \mathrm{H}), 7.79(\mathrm{~d}, \mathrm{~J}=7.7 \mathrm{~Hz}$, $2 \mathrm{H}), 7.68(\mathrm{~d}, J=7.8 \mathrm{~Hz}, 2 \mathrm{H}), 6.61(\mathrm{t}, J=7.7 \mathrm{~Hz}, 2 \mathrm{H})$. ${ }^{13} \mathrm{C}\left\{{ }^{1} \mathrm{H}\right\}$ NMR (101 MHz, $\left.\mathrm{CDCl}_{3}\right) \delta: 140.8,131.7$ (q, $J=32.4$ $\mathrm{Hz}), 130.7,129.7,124.9$ (q, $J=3.7 \mathrm{~Hz}), 124.23$ (q, J = 272.4 $\mathrm{Hz}), 124.20(\mathrm{q}, J=3.8 \mathrm{~Hz}) .{ }^{19} \mathrm{~F}$ NMR $\left(377 \mathrm{MHz} \mathrm{CDCl}_{3}\right) \delta$ : 62.68. GC-MS: $\mathrm{rt}=6.94 \mathrm{~min}, \mathrm{~m} / \mathrm{z}=290$. Column chromatography: $\mathrm{SiO}_{2}, n$-Pentane $100 \%$.

2,2'-bis(trifluoromethyl)-1,1'-biphenyl (12) ${ }^{22}$ Yield: 145.1 $\mathrm{mg}, 50 \%(\mathrm{X}=\mathrm{I}) ; 87.1 \mathrm{mg}, 30 \%(\mathrm{X}=\mathrm{Br}) ; 185.7 \mathrm{mg}, 64 \%(\mathrm{X}$ $=\mathrm{H}) .{ }^{1} \mathrm{H}$ NMR $\left(400 \mathrm{MHz}, \mathrm{CDCl}_{3}\right) \delta: 7.76(\mathrm{dd}, J=7.6,1.5 \mathrm{~Hz}$, $2 \mathrm{H}), 7.54(\mathrm{dd}, J=7.5,1.5 \mathrm{~Hz} 4 \mathrm{H}), 7.31(\mathrm{~d}, J=7.5 \mathrm{~Hz}, 2 \mathrm{H})$. ${ }^{13} \mathrm{C}\left\{{ }^{1} \mathrm{H}\right\}$ NMR $\left(101 \mathrm{MHz}, \mathrm{CDCl}_{3}\right) \delta: 137.7,131.7,130.8$, $129.0(\mathrm{q}, J=30.1 \mathrm{~Hz}), 128.3,126.2(\mathrm{~m}), 124.1(\mathrm{q}, J=274.2$ $\mathrm{Hz}){ }^{19} \mathrm{~F} \mathrm{NMR}\left(377 \mathrm{MHz}, \mathrm{CDCl}_{3}\right) \delta:-58.12$. GC-MS: $\mathrm{rt}=7.16$ min, $\mathrm{m} / \mathrm{z}=290$. Column chromatography: $\mathrm{SiO}_{2}$, petrolium ether $100 \%$.

2,2'-bipyridine $(13)^{25}$ Yield: $93.7 \mathrm{mg}, 60 \%(\mathrm{X}=\mathrm{Br}) .{ }^{1} \mathrm{H}$ NMR (400 MHz, $\left.\mathrm{CDCl}_{3}\right) \delta: 8.69(\mathrm{~d}, J=4.4 \mathrm{~Hz}, 2 \mathrm{H}), 8.40(\mathrm{~d}$, $J=8.0 \mathrm{~Hz}, 2 \mathrm{H}), 7.81(\mathrm{ddd}, J=7.9,2.8,1.4 \mathrm{~Hz}, 2 \mathrm{H}), 7.30$ (ddd, $J=7.4,4.8,1.2 \mathrm{~Hz}, 2 \mathrm{H}) .{ }^{13} \mathrm{C}\left\{{ }^{1} \mathrm{H}\right\}$ NMR $(101 \mathrm{MHz}$, $\left.\mathrm{CDCl}_{3}\right) \delta: 156.3,149.3,137.1,123.9,121.2 . \mathrm{GC}-\mathrm{MS}: \mathrm{rt}=7.51$ $\min , \mathrm{m} / \mathrm{z}=156$. Column chromatography: $\mathrm{Al}_{2} \mathrm{O}_{3}, n$ pentane/EtOAc 80/20.

1,1'-biisoquinoline $(\mathbf{1 4})^{26}$ Yield: $199.9 \mathrm{mg}, 78 \%(\mathrm{X}=\mathrm{I}) .{ }^{1} \mathrm{H}$ NMR (400 MHz, $\left.\mathrm{CDCl}_{3}\right) \delta: 8.72(\mathrm{~d}, J=5.7 \mathrm{~Hz}, 2 \mathrm{H}), 7.93(\mathrm{~d}$, $J=8.3 \mathrm{~Hz}, 2 \mathrm{H}), 7.80(\mathrm{~d}, J=5.7 \mathrm{~Hz}, 2 \mathrm{H}), 7.76(\mathrm{dd}, J=8.5,0.5$ $\mathrm{Hz}, 2 \mathrm{H}), 7.69$ (ddd, $J=8.3,6.8,1.1 \mathrm{~Hz}, 2 \mathrm{H}), 7.47$ (ddd, $J=$ 8.3, 6.8, $1.2 \mathrm{~Hz}, 2 \mathrm{H}) .{ }^{13} \mathrm{C}\left\{{ }^{1} \mathrm{H}\right\}$ NMR $\left(101 \mathrm{MHz}, \mathrm{CDCl}_{3}\right) \delta$ : 158.3, 142.1, 136.9, 130.4, 127.9, 127.6, 127.3, 127.0, 121.1. GC-MS: $\mathrm{rt}=12.22 \mathrm{~min}, \mathrm{~m} / \mathrm{z}=256$. Column chromatography: $\mathrm{Al}_{2} \mathrm{O}_{3}$, petrolium ether/EtOAc 70/30.

$1,1^{\prime}: 2^{\prime}, 1^{\prime \prime}: 2^{\prime \prime}, 1^{\prime \prime \prime}$-quaterphenyl (15) ${ }^{27}$ Yield: $291.1 \mathrm{mg}, 95 \%$ $(\mathrm{X}=\mathrm{Br}) .{ }^{1} \mathrm{H}$ NMR $\left(400 \mathrm{MHz}, \mathrm{CDCl}_{3}\right) \delta: 7.45-7.40(\mathrm{~m}, 2 \mathrm{H})$, 7.39-7.31 (m, 4H), 7.20-7.15 (m, 2H), $7.09(\mathrm{t}, J=7.3 \mathrm{~Hz}, 2 \mathrm{H})$, $7.01(\mathrm{t}, J=7.4 \mathrm{~Hz}, 4 \mathrm{H}), 6.62(\mathrm{~d}, J=7.2 \mathrm{~Hz}, 4 \mathrm{H}) .{ }^{13} \mathrm{C}\left\{{ }^{1} \mathrm{H}\right\}$ NMR (101 MHz, $\left.\mathrm{CDCl}_{3}\right)$ d: 141.2, 141.1, 140.2, 131.9, 130.1, 129.4, 127.63, 127.59, 127.2, 126.1. GC-MS: $\mathrm{rt}=11.50 \mathrm{~min}$, $\mathrm{m} / \mathrm{z}=306$. Column chromatography: $\mathrm{SiO}_{2}, n$-Pentane $100 \%$.

1,1'-binaphthalene (16) ${ }^{24}$ Yield: $234.0 \mathrm{mg}, 92 \%(\mathrm{X}=\mathrm{Br}) .{ }^{1} \mathrm{H}$ NMR (400 MHz, $\left.\mathrm{CDCl}_{3}\right) \delta:$ 7.98-7.95 (m, 4H), 7.65-7.57 (m, $2 \mathrm{H}), 7.52-7.47(\mathrm{~m}, 4 \mathrm{H}), 7.41(\mathrm{~d}, J=8.5 \mathrm{~Hz}, 2 \mathrm{H}), 7.34-7.28$ $(\mathrm{m}, 2 \mathrm{H}) .{ }^{13} \mathrm{C}\left\{{ }^{1} \mathrm{H}\right\}$ NMR $\left(101 \mathrm{MHz}, \mathrm{CDCl}_{3}\right) \delta: 138.7,133.7$, 133.0, 128.3, 128.1, 128.0, 126.8, 126.2, 126.0, 125.6. GCMS: $\mathrm{rt}=11.41 \mathrm{~min}, \mathrm{~m} / \mathrm{z}=254$. Column chromatography: $\mathrm{SiO}_{2}, n$-Pentane $100 \%$.

2,2'-binaphthalene $(17)^{5 a}$ Yield: $203.5 \mathrm{mg}, 80 \%(\mathrm{X}=\mathrm{Br})$. ${ }^{1} \mathrm{H}$ NMR (400 MHz, $\mathrm{CDCl}_{3}$ ) $\delta: 8.19$ (s, 2H), 7.99 - 7.95 (m, 
4H), $7.93-7.86(\mathrm{~m}, 4 \mathrm{H}), 7.59-7.48(\mathrm{~m}, 4 \mathrm{H}) .{ }^{13} \mathrm{C}\left\{{ }^{1} \mathrm{H}\right\} \mathrm{NMR}$ $\left(101 \mathrm{MHz}, \mathrm{CDCl}_{3}\right)$ \&: 138.6, 133.9, 132.9, 128.7, 128.4, 127.9, 126.6, 126.3, 126.2, 125.9. GC-MS: $\mathrm{rt}=12.78 \mathrm{~min}, \mathrm{~m} / \mathrm{z}=$ 254. Column chromatography: $\mathrm{SiO}_{2}, n$-Pentane $100 \%$.

1,2-diphenylethane $(\mathbf{1 8})^{28}$ Yield: $131.2 \mathrm{mg}, 72 \%(\mathrm{X}=\mathrm{Br})$. ${ }^{1} \mathrm{H}$ NMR (400 MHz, $\mathrm{CDCl}_{3}$ ) $\delta: 7.39-7.32(\mathrm{~m}, 4 \mathrm{H}), 7.30-7.25$ $(\mathrm{m}, 6 \mathrm{H}), 3.00(\mathrm{~s}, 4 \mathrm{H}),{ }^{13} \mathrm{C}\left\{{ }^{1} \mathrm{H}\right\}$ NMR $\left(101 \mathrm{MHz}, \mathrm{CDCl}_{3}\right) \delta$ : 142.0, 128.6, 128.5, 126.1, 38.1. GC-MS: $\mathrm{rt}=7.89 \mathrm{~min}, \mathrm{~m} / \mathrm{z}=$ 182. Column chromatography: $\mathrm{SiO}_{2}, n$-Pentane $100 \%$.

9,10-dihydrophenanthrene (19) ${ }^{29}$ Yield: $108.2 \mathrm{mg}, 60 \%(\mathrm{X}=$ Br). ${ }^{1} \mathrm{H}$ NMR (400 MHz, $\left.\mathrm{CDCl}_{3}\right) \delta: 7.81(\mathrm{~d}, \mathrm{~J}=7.7 \mathrm{~Hz}, 2 \mathrm{H})$, 7.39-7.33 (m, 2H), 7.29-7.27 (m, 4H), 2.93 (s, 4H). ${ }^{13} \mathrm{C}\left\{{ }^{1} \mathrm{H}\right\}$ NMR (101 MHz, $\left.\mathrm{CDCl}_{3}\right)$ $\delta: 137.6,134.7,128.3,127.6,127.1$, 123.9, 29.2. GC-MS: $\mathrm{rt}=8.77 \mathrm{~min}, \mathrm{~m} / \mathrm{z}=180$. Column chromatography: $\mathrm{SiO}_{2}, n$-Pentane $100 \%$.

4,4'-dichloro-1,1'-biphenyl (20) ${ }^{30}$ Yield: $140.6 \mathrm{mg}, 63 \%(\mathrm{X}$ $=\mathrm{I}) .{ }^{1} \mathrm{H}$ NMR $\left(400 \mathrm{MHz}, \mathrm{CDCl}_{3}\right) \delta: 7.49(\mathrm{~d}, J=8.6 \mathrm{~Hz}, 4 \mathrm{H})$, $7.42(\mathrm{~d}, J=8.6 \mathrm{~Hz}, 4 \mathrm{H}) .{ }^{13} \mathrm{C}\left\{{ }^{1} \mathrm{H}\right\}$ NMR $\left(101 \mathrm{MHz}, \mathrm{CDCl}_{3}\right) \delta$ : 138.6, 133.9, 129.2, 128.4. GC-MS: $\mathrm{rt}=9.239 \mathrm{~min}, \mathrm{~m} / \mathrm{z}=$ 223. Column chromatography: $\mathrm{SiO}_{2}, n$-Pentane $100 \%$.

3,3'-dichloro-1,1'-biphenyl (21) ${ }^{31}$ Yield: $100.4 \mathrm{mg}, 45 \%(\mathrm{X}$ $=\mathrm{Br}) .{ }^{1} \mathrm{H} \mathrm{NMR}\left(400 \mathrm{MHz}, \mathrm{CDCl}_{3}\right) \delta: 7.56-7.55(\mathrm{~m}, 2 \mathrm{H}), 7.46-$ $7.34(\mathrm{~m}, 6 \mathrm{H}) .{ }^{13} \mathrm{C}\left\{{ }^{1} \mathrm{H}\right\}$ NMR $\left(101 \mathrm{MHz}, \mathrm{CDCl}_{3}\right) \delta: 141.8$, 135.0, 130.3, 128.1, 127.5, 125.5. GC-MS: $\mathrm{rt}=9.218 \mathrm{~min}$, $\mathrm{m} / \mathrm{z}=222$. Column chromatography: $\mathrm{SiO}_{2}, n$-Pentane $100 \%$.

Triphenylene $(22)^{32}$ Yield: $207.7 \mathrm{mg}, 91 \%(\mathrm{X}=\mathrm{Br}) .{ }^{1} \mathrm{H}$ NMR (400 MHz, $\left.\mathrm{CDCl}_{3}\right) \delta: 8.68(\mathrm{dd}, J=6.2,3.4 \mathrm{~Hz}, 6 \mathrm{H})$, $7.68(\mathrm{dd}, J=6.3,3.3 \mathrm{~Hz}, 6 \mathrm{H}) .{ }^{13} \mathrm{C}\left\{{ }^{1} \mathrm{H}\right\} \mathrm{NMR}(101 \mathrm{MHz}$, $\left.\mathrm{CDCl}_{3}\right) \delta: 130.0,127.4,123.5$. GC-MS: $\mathrm{rt}=11.89 \mathrm{~min}, \mathrm{~m} / \mathrm{z}=$ 228. Column chromatography: $\mathrm{SiO}_{2}, n$-Pentane/DCM 90/10.

2,6,10-trimethyltriphenylene (23a) / 2,6,11trimethyltriphenylene (23b) $(1 / 3)^{33}$ Yield: $216.3 \mathrm{mg}, 80 \%(\mathrm{X}=$ Br). M.p. of mixture : $128^{\circ} \mathrm{C}$ (lit. for 23a: $181{ }^{\circ} \mathrm{C}^{34 \mathrm{a}}$; lit. for 23b: $142{ }^{\circ} \mathrm{C}$ ) ${ }^{34 \mathrm{~b}, \mathrm{c} 1} \mathrm{H}$ NMR (400 MHz, $\left.\mathrm{CDCl}_{3}\right) \delta: 8.53(\mathrm{~d}, J=$ $8.3 \mathrm{~Hz}, 2 \mathrm{H}), 8.52(\mathrm{~d}, J=8.2 \mathrm{~Hz}, 2 \mathrm{H}), 8.49(\mathrm{~d}, J=8.3 \mathrm{~Hz}, 2 \mathrm{H})$, 8.48 (d, $J=8.2 \mathrm{~Hz}, 2 \mathrm{H}), 8.44$ (br s, $2 \mathrm{H}), 8.41$ (br s, $2 \mathrm{H}), 7.48$ $7.44(\mathrm{~m}, 4 \mathrm{H}), 2.64(\mathrm{~s}, 6 \mathrm{H}), 2.63(\mathrm{~s}, 6 \mathrm{H}) .{ }^{13} \mathrm{C}\left\{{ }^{1} \mathrm{H}\right\}$ NMR $(101$ $\left.\mathrm{MHz}, \mathrm{CDCl}_{3}\right) \delta: 136.8,136.7,136.43,136.37,130.1,130.0$, $129.7,129.5,128.63,128.57,128.33,128.27,127.9,127.7$, $127.4,127.2$, 123.40, 123.35, 123.3, 123.24, 123.19, 123.17, 123.1, 22.0. HRMS $\left(\mathrm{ESI}^{+}\right) \mathrm{m} / \mathrm{z}$ : $[\mathrm{M}+\mathrm{H}]^{+}$Calcd. for $\mathrm{C}_{21} \mathrm{H}_{19}$ 271.1487; Found : 271.1481. Column chromatography: $\mathrm{SiO}_{2}$, $n$-Pentane/DCM 90/10. A small crop of crystals suitable for Xray diffraction studies of $\mathbf{2 3 b}$ were obtained by slow diffusion of pentane into a dichloromethane solution of the mixture.

1,4-diphenylbuta-1,3-diyne (24) ${ }^{35}$ Yield: $192.1 \mathrm{mg}, 95 \%(\mathrm{X}$ $=\mathrm{H}) .{ }^{1} \mathrm{H}$ NMR $\left(400 \mathrm{MHz}, \mathrm{CDCl}_{3}\right) \delta: 7.60-7.53(\mathrm{~m}, 4 \mathrm{H}), 7.43-$ $7.34(\mathrm{~m}, 6 \mathrm{H}) .{ }^{13} \mathrm{C}\left\{{ }^{1} \mathrm{H}\right\}$ NMR (101 $\left.\mathrm{MHz}, \mathrm{CDCl}_{3}\right) \delta: 132.7$, 129.4, 128.6, 122.0, 81.7, 74.1. GC-MS: $\mathrm{rt}=10.20 \mathrm{~min}, \mathrm{~m} / \mathrm{z}=$ 202. Column chromatography: $\mathrm{SiO}_{2}, n$-Pentane/DCM 50/50.

1,1'-dimethyl-1H,1'H-2,2'-bibenzo[d]imidazole $(25)^{36}$ Yield: $196.7 \mathrm{mg}, 75 \%(\mathrm{X}=\mathrm{H}) .{ }^{1} \mathrm{H}$ NMR $\left(400 \mathrm{MHz}, \mathrm{CDCl}_{3}\right) \delta: 7.89$ $(\mathrm{d}, J=7.6 \mathrm{~Hz}, 2 \mathrm{H}), 7.51(\mathrm{~d}, J=7.6 \mathrm{~Hz}, 2 \mathrm{H}), 7.52-7.35(\mathrm{~m}$, $4 \mathrm{H}), 4.35(\mathrm{~s}, 6 \mathrm{H}) .{ }^{13} \mathrm{C}\left\{{ }^{1} \mathrm{H}\right\} \mathrm{NMR}\left(101 \mathrm{MHz}, \mathrm{CDCl}_{3}\right) \delta: 143.5$, $142.8,136.4,124.2,123.1,120.5,110.3,32.6$. GC-MS: $\mathrm{rt}=$ $12.61 \mathrm{~min}, \mathrm{~m} / \mathrm{z}=262$. Column chromatography: $\mathrm{SiO}_{2}, n$ Pentane/EtOAc 50/50.
1,1'-dimethyl-1H,1'H-2,2'-bipyrrole (26) Yield: $32.0 \mathrm{mg}$, $20 \%(\mathrm{X}=\mathrm{H}) .{ }^{1} \mathrm{H}$ NMR $\left(400 \mathrm{MHz}, \mathrm{CDCl}_{3}\right)$ : $:$ 6.74-6.73 (m, $2 \mathrm{H}), 6.21-6.17(\mathrm{~m}, 4 \mathrm{H}), 3.53(\mathrm{~s}, 6 \mathrm{H}) .{ }^{13} \mathrm{C}\left\{{ }^{1} \mathrm{H}\right\}$ NMR $(101$ $\mathrm{MHz}, \mathrm{CDCl}_{3}$ ) $\delta: 125.9,122.9,110.7,107.5$, 34.6. GC-MS: rt $=6.941 \mathrm{~min}, \mathrm{~m} / \mathrm{z}=160$. HRMS $\left(\mathrm{ESI}^{+}\right) \mathrm{m} / \mathrm{z}:[\mathrm{M}+\mathrm{H}]^{+}$Calcd. for $\mathrm{C}_{10} \mathrm{H}_{13} \mathrm{~N}_{2}$ 161.1079; Found : 161.1079. Column chromatography: $\mathrm{SiO}_{2}, n$-Pentane/DCM 20/80.

Biferrocenyl (27) Yield: $148.0 \mathrm{mg}, 40 \%(\mathrm{X}=\mathrm{H}) .{ }^{1} \mathrm{H}$ NMR $\left(400 \mathrm{MHz}, \mathrm{CDCl}_{3}\right) \delta: 4.38-4.35(\mathrm{~m}, 4 \mathrm{H}), 4.19-4.17$ (m, 4H),

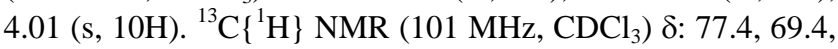
67.8, 66.6. GC-MS: $\mathrm{rt}=12.687 \mathrm{~min}, \mathrm{~m} / \mathrm{z}=370$. HRMS $\left(\mathrm{ESI}^{+}\right)$ $\mathrm{m} / \mathrm{z}:[\mathrm{M}+\mathrm{H}]^{+}$Calcd. for $\mathrm{C}_{20} \mathrm{H}_{19} \mathrm{Fe}_{2}$ 371.0118; Found : 371.0107. Column chromatography: $\mathrm{SiO}_{2}, n$-Pentane/EtOAc $95 / 5$.

\section{ASSOCIATED CONTENT}

\section{Supporting Information}

Optimization tables, NMR spectra for all synthetic compounds, X-ray diffraction and mechanistic study details for ESI-MS and DFT. CCDC 1564505 contains the supplementary crystallographic data for this paper. This material is available free of charge via the Internet at http://pubs.acs.org.

\section{AUTHOR INFORMATION}

\section{Corresponding Author}

*marc.taillefer@enscm.fr

Notes

The authors declare no competing financial interests.

\section{ACKNOWLEDGMENT}

ANR (program CD2I - CuFeCCBondCat) is greatly acknowledged for financial support.

\section{REFERENCES}

(1) (a) Carney, J. R.; Dillon, B. R.; Thomas, S. P. Recent Advances of Manganese Catalysis for Organic Synthesis. Eur. J. Org. Chem. 2016, 3912-3929; C-H bond formation: (b) Iwasaki, K.; Wan, K. K.; Oppedisano, A.; Crossley, S. W. M.; Shenvi, R. A. Simple, Chemoselective Hydrogenation with Thermodynamic Stereocontrol. J. Am. Chem. Soc. 2014, 136, 1300-1303; C-O bond formation: (c) Krishnan, K. K.; Thomas, A. M.; Sindhu, K. S.; Anilkumar, G. Recent advances and perspectives in the manganese-catalysed epoxidation reactions. Tetrahedron 2016, 72, 1-16; C-N bond formation: (d) Kim, J. Y.; Cho, S. H.; Joseph, J.; Chang, S. Cobalt- and ManganeseCatalyzed Direct Amination of Azoles under Mild Reaction Conditions and the Mechanistic Details. Angew. Chem. Int. Ed. 2010, 49, 9899-9903; (e) Paradine, S. M.; Griffin, J. R.; Zhao, J.; Petronico, A. L.; Miller, S. M.; White, M. C. A manganese catalyst for highly reactive yet chemoselective intramolecular $\mathrm{C}\left(\mathrm{sp}^{3}\right)-\mathrm{H}$ amination. Nat. Chem. 2015, 7, 987-994; C-X bond formation: (f) Liu, W.; Groves, J. T. Manganese Catalyzed C-H Halogenation. Acc. Chem. Res. 2015, 48, 1727-1735.

(2) Sun, X.; Li, X.; Song, S.; Zhu, Y.; Liang, Y. -F.; Jiao, N. Mn-Catalyzed Highly Efficient Aerobic Oxidative Hydroxyazidation of Olefins: A Direct Approach to $\beta$-Azido Alcohols. J. Am. Chem. Soc. 2015, 137, 6059-6066.

(3) Yang, Y.; Liu, Y.; Jiang, Y.; Zhang, Y.; Vicic, D. A. Manganese-Catalyzed Aerobic Oxytrifluoromethylation of Styrene Derivatives Using $\mathrm{CF}_{3} \mathrm{SO}_{2} \mathrm{Na}$ as the Trifluoromethyl Source. J. Org. Chem. 2015, 80, 6639-6648.

(4) Yamamoto, D.; Oguro, T.; Tashiro, Y.; Soga, M.; Miyashita, K.; Aso, Y.; Makino, K. Manganese-Promoted Oxidative Cyclization of Unsaturated Oximes Using Molecular Oxygen in Air under Ambient Conditions. Eur. J. Org. Chem. 2016, 5216-5219. 
(5) (a) Cahiez,G.; Moyeux, A.; Buendia, J.; Duplais, C. Manganese- or Iron-Catalyzed Homocoupling of Grignard Reagents Using Atmospheric Oxygen as an Oxidant. J. Am. Chem. Soc. 2007, 129, 13788-13789; (b) Cahiez, G.; Duplais, C.; Buendia, J. ManganeseCatalyzed Oxidative Cross-Coupling of Grignard Reagents with Oxygen as an Oxidant. Angew. Chem. Int. Ed. 2009, 48, 6731-6734; (c) Bottoni, A.; Cahiez, G.; Calvaresi, M.; Moyeux, A.; Giacinto, P.; Miscione, G. P. A mechanistic insights into manganese-catalyzed oxidative homocoupling reactions of Grignard reagents: A computational DFT investigation. J. Organomet. Chem. 2016, 814, 25-34; (d) Ghaleshahi, H. G.; Antonacci, G.; Madsen, R. Manganese-Catalyzed Aerobic Heterocoupling of Aryl Grignard Reagents. Eur. J. Org. Chem. 2017, 1331-1336.

(6) (a) Mukhopadhyay, S.; Mandal, S. K.; Bhaduri, S.; Armstrong, W. H. Manganese Clusters with Relevance to Photosystem II. Chem. Rev. 2004, 104, 3981-4026; (b) Lee, C.-M.; Chuo, C.-H.; Chen, C.-H.; Hu, C.-C.; Chiang, M.-H.; Tseng, Y.-J.; Hu, C.-H.; Lee, G.-H. Structural and Spectroscopic Characterization of a Monomeric Side-On Manganese(IV) Peroxo Complex. Angew. Chem. Int. Ed. 2012, 51, 5427-5430; (c) Coggins, M. K.; Sun, X.; Kwak, Y.; Solomon, E. I.; Rybak-Akimova, E.; Kovacs, J. A. Characterization of Metastable Intermediates Formed in the Reaction between a Mn(II) Complex and Dioxygen, Including a Crystallographic Structure of a Binuclear Mn(III)-Peroxo Species. J. Am. Chem. Soc. 2013, 135, 5631-5640; (d) Colmer, H. E.; Howcroft, A. W.; Jackson, T. A. Formation, Characterization, and O-O Bond Activation of a Peroxomanganese(III) Complex Supported by a Cross-Clamped Cyclam Ligand. Inorg. Chem. 2016, 55, 2055-2069; (e) Brazzolotto, D.; Reinhard, F. G. C.; Smith-Jones, J.; Retegan, M.; Amidani, L.; Faponle, A. S.; Ray, K.; Phhilouze, C.; de Visser, S. P.; Gennari, M.; Duboc, C. A High-Valent Non-Heme $\mu$-Oxo Manganese(IV) Dimer Generated from a Thiolate-Bound Manganese(II) Complex and Dioxygen. Angew. Chem. Int. Ed. 2017, 56, 8211-8215.

(7) General synthesis of biaryls and their applications: (a) Hassan, J.; Sévignon, M.; Gozzi, C.; Schulz, E.; Lemaire, M. Aryl-Aryl Bond Formation One Century after the Discovery of the Ullmann Reaction. Chem. Rev. 2002, 102, 1359-1470; (b) Cepanec, I. (Ed.) Synthesis of Biaryls, Elsevier Ltd., Oxford, 2004; (c) Boldi, A. M. Libraries from natural product-like scaffolds. Curr. Opin. Chem. Biol. 2004, 8, 281-286; (d) Kertesz, M.; Choi, C. H.; Yang, S. Conjugated Polymers and Aromaticity. Chem. Rev. 2005, 105, 3448-3481; (e) Bringmann, G.; Gulder, T.; Gulder, T. A. M.; Breuning, M. Atroposelective Total Synthesis of Axially Chiral Biaryl Natural Products. Chem. Rev. 2011, 111, 563-639. (f) de Meijere, A.; Bräse, S.; Oestreich, M. (Eds.) Metal-Catalyzed Cross-Coupling Reactions, Vol. 1, Wiley-VCH, Weinheim, 2013.

(8) Examples for transition-metal catalyzed coupling reactions involving aryllithium compounds: (a) Jhaveri, S. B.; Carter, K. R. Nickel-Catalyzed Coupling of Aryl Bromides in the Presence of Alkyllithium Reagents. Chem. Eur. J. 2008, 14, 6845-6848; (b) Smith, III, A. B.; Hoye, A. T.; Martinez-Solorio, D.; Kim, W.-S.; Tong, R. Unification of Anion Relay Chemistry with the Takeda and Hiyama Cross-Coupling Reactions: Identification of an Effective Silicon-Based Transfer Agent. J. Am. Chem. Soc. 2012, 134, 45334536; (c) Lu, F. Vanadium(IV) tetrachloride catalyzed oxidative homo-coupling of aryl lithium under mild reaction condition. Tetrahedron Lett. 2012, 53, 2444-2446; (d) Toummini, D.; Ouazzani, F.; Taillefer, M. Iron-Catalyzed Homocoupling of Aryl Halides and Derivatives in the Presence of Alkyllithiums. Org. Lett. 2013, 15, 4690-4693; (e) Giannerini, M.; Fañanás-Mastral, M.; Feringa, B. L. Direct catalytic cross-coupling of organolithium compounds. Nat. Chem. 2013, 5, 667-672; (f) Tao, J.-L.; Wang, Z.-X. Nickel-Catalyzed Cross-Coupling of (Hetero)aryl Chlorides with Aryllithium Compounds. Asian J. Org. Chem. 2016, 5, 521-527; (g) Buter, J.; Heijnen, D.; Vila, C.; Hornillos, V.; Otten, E.; Giannerini, M.; Minnaard, A. J.; Feringa, B. L. Palladium-Catalyzed, tert-Butyllithium-Mediated Dimerization of Aryl Halides and Its Application in the Atropselective Total Synthesis of Mastigophorene A. Angew. Chem. Int. Ed. 2016, 55, 3620-3624; (h) Pinxterhuis, E. B.; Visser, P.; Esser, I.; Gualtierotti, J-B.; Feringa, B. L. Fast, Efficient and Low E-Factor
One-Pot Palladium-Catalyzed Cross-Coupling of (Hetero)Arenes. Angew. Chem. Int. Ed. 2018, 57, 9452-9455.

(9) Freeman, P. K.; Hutchinson, L. L. Alkyllithium reagents from alkyl halides and lithium radical anions. J. Org. Chem. 1980, 45, 1924-1930

(10) Gilman, H.; Jones, R. G. Halogen-Metal Interconversion Reaction with Organolithium Compounds. Org. React. 1951, 6, 339356.

(11) (a) Togni, A.; Venanzi, L. M. Nitrogen Donors in Organometallic Chemistry and Homogeneous Catalysis. Angew. Chem. Int. Ed. 1994, 33, 497-526; (b) Ashby, M. T.; Govindan, G. N.; Grafton, A. K. Metal-Assisted Racemization of the Atropisomers of a 1,1'Binaphthyl Skeleton via a Syn Transition State. J. Am. Chem. Soc. 1994, 116, 4801-4809; (c) Buonomo, J. A.; Everson, D. A.; Weix, D. J. Substituted 2,2'-bipyridines by nickel-catalysis: 4,4'-di-tertbutyl2,2'-bipyridine. Synthesis 2013, 45, 3099-3102.

(12) Applications of the compounds 15, 16 and 17 in polycyclic aromatic compound synthesis: (a) Snyder, J. A.; Bragg, A. E. Structural Control of Nonadiabatic Bond Formation: The Photochemical Formation and Stability of Substituted 4a,4b-Dihydrotriphenylenes. $J$. Phys. Chem. A. 2015, 119, 3972-3985; (b) Uchida, K.; Ito, S.; Nakano, M.; Abe, M.; Kubo, T. Biphenalenylidene: Isolation and Characterization of the Reactive Intermediate on the Decomposition Pathway of Phenalenyl Radical. J. Am. Chem. Soc. 2016, 138, 2399-2410.

(13) Compound 19 can be obtained by an intramolecular cyclization: (a) Revol, G.; McCallum, T.; Morin, M.; Gagosz, F.; Barriault, L. Photoredox Transformations with Dimeric Gold Complexes. Angew. Chem. Int. Ed. 2013, 52, 13342-13345; (b) Corrie, T. J. A.; Ball, L. T.; Russell, C. A.; Lloyd-Jones, G. C. Au-Catalyzed Biaryl Coupling To Generate 5- to 9-Membered Rings: Turnover-Limiting Reductive Elimination versus $\pi$-Complexation. J. Am. Chem. Soc. 2017, 139, 245-254; or by a reduction of phenanthrene: (c) Chciuk, T. V.; Li, A. M.; Vazquez-Lopez, A.; Anderson, W. R.; Flowers II, Jr. R. A. Secondary Amides as Hydrogen Atom Transfer Promoters for Reactions of Samarium Diiodide. Org. Lett. 2017, 19, 290-293.

(14) (a) Peña, D.; Escudero, S.; Pérez, D.; Guitián, E.; Castedo, L. Efficient Palladium-Catalyzed Cyclotrimerization of Arynes: Synthesis of Triphenylenes. Angew. Chem. Int. Ed. 1998, 37, 26592661; (b) Watson, M. D.; Fechtenkötter, A.; Müllen, K. Big Is Beautiful-"Aromaticity" Revisited from the Viewpoint of Macromolecular and Supramolecular Benzene Chemistry. Chem. Rev. 2001, 101, $1267-1300$

(15) Snieckus, V. Directed ortho metalation. Tertiary amide and O-carbamate directors in synthetic strategies for polysubstituted aromatics. Chem. Rev. 1990, 90, 879-933.

(16) Garden, J. A.; Armstrong, D. R.; Clegg, W.; GarcíaAlvarez, J.; Hevia, E.; Kennedy, A. R.; Mulvey, R. E.; Robertson, S. D.; Russo, L. Donor-Activated Lithiation and Sodiation of Trifluoromethylbenzene: Structural, Spectroscopic, and Theoretical Insights. Organometallics 2013, 32, 5481-5490.

(17) (a) Engtrakul, C.; Sita, L. R. Ferrocene-Based Nanoelectronics: Regioselective Syntheses and Electrochemical Characterization of $\alpha$-Monothiol and $\alpha, \omega$-Dithiol, Phenylethynyl-Conjugated, 2,5Diethynylpyridyl- and Pyridinium-Linked Diferrocene Frameworks Having an End-to-End Distance of $\sim 4 \mathrm{~nm}$. Organometallics 2008, 27, 927-937; (b) Wilson, L. E.; Hassenrück, C.; Winter, R. F.; White, A. J. P.; Albrecht, T.; Long, N. J. Functionalised Biferrocene Systems towards Molecular Electronics. Eur. J. Inorg. Chem. 2017, 496-504.

(18) (a) Rausch, M. D. Ferrocene and Related Organometallic $\pi$ Complexes. IV. Some Ullmann Reactions of Haloferrocenes. J. Org. Chem. 1961, 26, 1802-1805; (b) Talham, D. R.; Cowan, D. O. Synthesis of new biferrocene derivatives containing interannular bridges and their mixed-valence analogs. Organometallics 1987, 6, 932-937.

(19) see computational details in the Supporting Information.

(20) (a) Beermann, C.; Clauss, K. Organische ManganVerbindungen. Angew. Chem. 1959, 71, 627; (b) DFT calculations (See the SI) showed that the transmetallation reaction $\mathrm{Mn}(\mathrm{Cl})_{2}(\mathrm{THF})_{2}$ $+2 \mathrm{ArLi}(\mathrm{THF})_{3} \rightarrow \mathrm{Mn}(\mathrm{Ar})_{2}(\mathrm{THF})_{2}+2 \mathrm{ClLi}(\mathrm{THF})_{3}$ is strongly exergonic with $\Delta \mathrm{G}=-57.8 \mathrm{kcal} \mathrm{mol}^{-1}$.

(21) (a) Schwindeman, J. A.; Woltermann, C. J.; Letchford, R. J. Safe handling of organolithium compounds in the laboratory. Chemi- 
cal Health and Safety 2002, 9, 6-11. (b) Luisi, R.; Capriati, V. Lithium Compounds in Organic Synthsis. Wiley-VCH Verlag GmbH \& Co. KGaA. 2014.

(22) Moncomble, A.; Le Floch, P.; Gosmini, C. Cobalt- Catalyzed Formation of Symmetrical Biaryls and Its Mechanism. Chem. Eur. J. 2009, 15, 4770-4774.

(23) Cahiez, G.; Chaboche, C.; Mahuteau-Betzer, F.; Ahr, M. Iron-Catalyzed Homo-Coupling of Simple and Functionalized Arylmagnesium Reagents. Org. Lett. 2005, 7, 1943-1946.

(24) Cheng, G.; Luo, M. Homocoupling of Arylboronic Acids Catalyzed by $\mathrm{CuCl}$ in Air at Room Temperature. Eur. J. Org. Chem. 2011, 2519-2523.

(25) Shen, W.; Trötscher-Kaus, G.; Lippert, B. ${ }^{1} \mathrm{H}$ NMR spectroscopic identification of binding modes of 2,2'bipyridine ligands in complexes of square-planar $\mathrm{d}^{8}$ metal ions. Dalton Trans. 2009, 8203-8214.

(26) Frediani, P.; Giannelli, C.; Salvini, A.; Lanelli, S. Ruthenium complexes with $1,1^{\prime}$-biisoquinoline as ligand. Synthesis and hydrogenation activity. J. Organomet. Chem. 2003, 667, 197-208.

(27) Ozasa, S.; Fujioka, Y.; Okada, M.; Izumi, H.; Ibuki, E. Syntheses and Physical Properties of Several Deuterium-labelled Polyphenyls. Chem. Pharma. Bull. 1981, 29, 370-378.

(28) Black, P. J.; Edwards, M. G.; Williams, J. M. J. Borrowing Hydrogen: Indirect "Wittig" Olefination for the Formation of C-C Bonds from Alcohols. Eur. J. Org. Chem. 2006, 4367-4378.

(29) Deng, R.; Sun, L.; Li, Z. Nickel-catalyzed Carboannulation Reaction of $o$-Bromobenzyl Zinc Bromide with Unsaturated Compounds. Org. Lett. 2007, 9, 5207.

(30) Yuan, Y.; Bian, Y. Efficient homocoupling reactions of halide compounds catalyzed by manganese (II) chloride. Appl. Organometal. Chem. 2008, 22, 15-18.
(31) Mitsudo, K.; Shiraga, T.; Kagen, D.; Shi, D.; Becker, J. Y.; Tanaka, H. Pd/TEMPO-catalyzed electrooxidative synthesis of biaryls from arylboronic acids or arylboronic esters. Tetrahedron 2009, 65, 8384-8388.

(32) Hsieh, J.; Cheng, C. $O$-Dihaloarenes as aryne precursors for nickel-catalyzed $[2+2+2]$ cycloaddition with alkynesand nitriles. Chem. Commun. 2008, 2992-2994.

(33) García-López, J.-A.; Greaney, M. F. Use of 2Bromophenylboronic Esters as Benzyne Precursors in the PdCatalyzed Synthesis of Triphenylenes. Org. Lett. 2014, 16, 23382341.

(34) (a) Shirai, H.; Amano, N.; Hashimoto, Y.; Fukui, E.; Ishii, Y.; Ogawa, M. Trisannelated benzene synthesis by zirconium halide catalyzed cyclodehydration of cycloalkanones. J. Org. Chem. 1991, 56, 2253-2256; (b) Gant, A. A.; Lee, R.; Greaney, M. F. Generation of benzyne from benzoic acid using $\mathrm{C}-\mathrm{H}$ activation. Chem. Commun. 2010, 46, 8671-8673; (c) Jafarpour, F.; Hazrati, H.; Nouraldinmousa, S. Three-Bond Breaking of Cyclic Anhydrides: Easy Access to Polyfunctionalized Naphthalenes and Phenanthrenes. Org. Lett. 2013, 15, 3816-3819.

(35) Kakusawa, N.; Yamaguchi, K.; Kurita, J. Palladiumcatalyzed cross-coupling reaction of ethynylstibanes with organic halides. J. Organomet. Chem. 2005, 690, 2956-2966.

(36) Truong, T.; Alvarado, J.; Tran, L. D.; Daugulis, O. Nickel, Manganese, Cobalt, and Iron-Catalyzed Deprotonative Arene Dimerization. Org. Lett. 2010, 12, 1200-1203. 


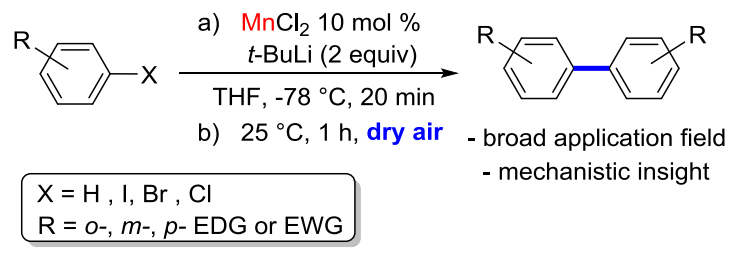

Insert Table of Contents artwork here 